\title{
Antibiotic activity of Plectranthus ornatus Codd., a Traditional Medicinal Plant
}

\author{
FERNANDA R. NASCIMENTO ${ }^{1}$, KAMYLLA R.S. ALBUQUERQUE ${ }^{1}$, MARCOS R. OLIVEIRA ${ }^{1}$, \\ VIRGINIA R. PIZZIOLO ${ }^{1}$, BEATRIZ G. BRASILEIRO ${ }^{2}$, GASPAR DIAZ ${ }^{3}$ and MARISA A.N. DIAZ
}

\author{
${ }^{1}$ Departamento de Bioquímica e Biologia Molecular, Universidade Federal de Viçosa, Avenida \\ Peter Henry Rolfs, s/n, Campus Universitário, 36570-900 Viçosa, MG, Brazil \\ ${ }^{2}$ Instituto Federal do Sudeste de Minas Gerais, Avenida Coronel Monteiro de Castro, 550, 36880-000 Muriaé, MG, Brazil \\ ${ }^{3}$ Instituto de Ciências Exatas, Universidade Federal de Minas Gerais, Avenida Presidente \\ Antônio Carlos, 6627, Pampulha, 31270-901 Belo Horizonte, MG, Brazil
}

Manuscript received on February 7, 2017; accepted for publication on July 24, 2017

\begin{abstract}
The dichloromethane extract of Plectranthus ornatus Codd., a tradicional medicinal plant, showed antibiotic activity with minimum inhibitory concentration (MIC) values of $0.4 \mathrm{mg} \cdot \mathrm{mL}^{-1}$ and 100 percent of biofilm inhibition against Staphylococcus aureus strains isolated from animals with mastitis infections. Based on these antibacterial activities, in addition to ethnopharmacological reports from healing men and farmers in Brazil, an herbal soap was produced from this active extract and was tested both in vitro and in vivo. In vivo assays conducted on these herbal soaps led to results similar to those previously conducted with the active extract. These results indicated the great potential of this plant for use as an excipient by preparing herbal antibacterial soaps as an alternative veterinary medicine aimed at controlling bovine mastitis infections on small Brazilian farms.
\end{abstract}

Key words: bovine mastitis, herbal soaps, Plectranthus ornatus, Staphylococcus aureus.

\section{INTRODUCTION}

Plectranthus ornatus Codd. (family Lamiaceae), is an ornamental and traditional medicinal plant, popularly known in Brazil as "Boldinho" (Lukhoba et al. 2006). It is African native plant which was brought to the Americas by the Portuguese. Ethnopharmacological studies have recommended the use of this plant to treat digestive problems. However, P. ornatus leaves have been used by healing men and farmers, in some regions of Brazil, as an antibiotic for the treatment of skin infections

Correspondence to: Marisa A.N. Diaz

E-mail: marisanogueira@ufv.br
(Brasileiro et al. 2006, Diaz et al. 2010). Ethno veterinary practices using $P$. ornatus leaves have become very common as a viable and alternative treatment method, as these leaves are safe, easy to obtain, and inexpensive, they can be found on small farms, and they represent a less aggressive method to heal animals. Most farmers' approaches are based on empirical knowledge, having achieved significant results in cattle (Marinho et al. 2007). Therefore, some farmers in Brazil have reported the use of this plant to treat bovine mastitis, an inflammation of the mammary gland, which is characterized by physical, chemical, and bacteriological changes in the milk caused by 
Staphylococcus aureus. This bacterium produces biofilms, a group of cells that adhere to a surface, and is frequently embedded within a self-produced matrix of an extracellular polymeric substance that causes a dramatic decrease in its susceptibility to the antimicrobial agents. This formation is considered an important virulence factor that is frequently associated with clinical infections (Otto 2008).

The genus Plectranthus is rich in diterpenes and triterpenes. This class of compounds had shown antimicrobial activity (Wellsow et al. 2006, Stavri et al. 2009). The ability of this genus to produce antimicrobial metabolites has led to several phytochemical studies around the word through the isolation of several antimicrobial diterpenes, such as plectrornatin A and two labdane derivatives, as well as plectrornatins B and C (Rijo et al. 2014). The biological activities of the compounds from the genus Plectranthus, associated with their Ethnopharmacological use reported by healing men and farmers, aroused our interest in developing an herbal soap from this plant that can specifically be used by milkers on small farms to wash their hands and milking utensils.

\section{MATERIALS AND METHODS}

\section{PLANT MATERIAL AND EXTRACTION}

Samples of $P$. ornathus Codd. were grown in a greenhouse at the Horticultural Department of the Federal University of Viçosa (UFV), Minas Gerais, Brazil. The plants were propagated by cuttings rooted in pre-commercial substrate (Plantmax

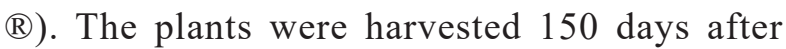
transplantation and growth. The plants were cut close to the ground, and the aerial parts (leaves) were dried at $40^{\circ} \mathrm{C}$ for 20 days in an air circulation oven, after which they were grinded into a fine powder. A voucher (39644) was deposited in the herbarium of the Department of Botany of UFV. Forty grams of powder were extracted using petrol, dichloromethane, and ethanol $(400 \mathrm{~mL})$ for $1 \mathrm{~h}$ at room temperature, applying the ultrasound method for 10 days for each solvent. The solvents were removed under vacuum at $40^{\circ} \mathrm{C}$ and stored at $4^{\circ} \mathrm{C}$.

\section{MICROORGANISMS TESTING}

The bacterial resistant strains $(3828,4075,4125$, and 4158) were isolated from animals with mastitis infections, which were kindly provided by Embrapa Dairy Cattle - Laboratory of Milk Microbiology (Juiz de Fora, Minas Gerais, Brazil), and purchased from the American Type Culture Collection (ATCC, 29213). Bacteria were routinely cultured in brain heart infusion (BHI) at $37^{\circ} \mathrm{C}$ for $18 \mathrm{~h}$ prior to experiments, and cell concentration was adjusted to $10^{6} \mathrm{CFU} \cdot \mathrm{mL}^{-1}$ by optical density at $600 \mathrm{~nm}$. Stock cultures were maintained in BHI containing glycerol at $-80^{\circ} \mathrm{C}$.

\section{ANTIBACTERIAL SUSCEPTIBILITY TESTING}

Hole-plate diffusion assay was initially performed to test the antibacterial activity of the crude extracts. To perform the assay, bacteria were cultivated overnight and a suspension containing $10^{6}$ CFU.mL ${ }^{-1}$ was spread on plates containing Müeller-Hinton agar $\left(\right.$ Himedia $\left.^{\circledR}\right)$. Holes (5) of approximately $5 \times 3 \mathrm{~mm}$ were made in the agar and were filled with $30 \mu \mathrm{L}$ of the extract stock solution $\left(50 \mathrm{mg} \cdot \mathrm{mL}^{-1}\right)$. After incubation at $37^{\circ} \mathrm{C}$ for $24 \mathrm{~h}$, inhibition zones were measured in millimeters and compared to the controls. The controls were prepared with $30 \mu \mathrm{L}$ of DMSO (negative control) and $5 \mathrm{mg} \cdot \mathrm{mL}^{-1}$ of ciclopirox olamine (Uci-Farma ${ }^{\circledR}$ ). This antibiotic was used as the positive control due to its antibacterial properties (Jue et al. 1985). Inhibition zones greater than $7 \mathrm{~mm}$ were considered positive (Nascimento et al. 2000) Student's t-test $(p<0.05)$ was performed to compare the results of the inhibition zones obtained from the extracts with the positive control. Tests were performed twice in triplicate. 
MINIMAL INHIBITORY CONCENTRATION (MIC) ASSAY

Extract activity on bacterial growth was determined by applying the microdilution method (CLSI 2009). The microorganisms were initially cultured in Petri dishes containing BHI agar (Himedia ${ }^{\circledR}$ ), which were incubated for 24 hours at $37^{\circ} \mathrm{C}$. Subsequently, the isolated colonies were subcultured in MuellerHinton broth (Himedia $\left.{ }^{\circledR}\right)$, which was incubated at $37^{\circ} \mathrm{C}$ for $180 \mathrm{rpm}$ until the culture reached the exponential phase. These colonies were then diluted to an optical density corresponding to 0.5 in the McFarland standard scale $\left(\mathrm{OD}_{620}=0.10\right)$. Microplate holes were filled with $100 \mu$ L of MuellerHinton broth (Himedia ${ }^{\circledR}$ ) extracts containing concentrations ranging from $0.1 \mathrm{mg} \cdot \mathrm{mL}^{-1}$ to 10 mg. $\mathrm{mL}^{-1}$ and $10^{6} \mathrm{CFU} \cdot \mathrm{mL}^{-1}$ bacterial suspensions. Whereas the DMSO could be bactericidal a control of microbial growth in this solvent was done with $100 \mu \mathrm{L}$ of bacterial suspension and $100 \mu \mathrm{L}$ of Müeller-Hinton broth with DMSO at the highest concentration used in the preparation of the extract. After $24 \mathrm{~h}$ at $37^{\circ} \mathrm{C}, 4 \mu \mathrm{L}$ of $p$-iodonitrotetrazolium (INT, I8377, Sigma ${ }^{\circledR}$ ) was added to each well, and the plate was incubated for an additional $2 \mathrm{~h}$ at $37^{\circ} \mathrm{C}$. A change in the color of the medium from yellow to pink-violet was used as an indication of bacterial growth. The minimal inhibitory concentration of the antibiotics was determined by the same procedure, with concentrations ranging from $0.1 \mu \mathrm{g} \cdot \mathrm{mL}^{-1}$ a $500 \mu \mathrm{g} \cdot \mathrm{mL}^{-1}$.

\section{BIOFILM INHIBITORY CONCENTRATION (BIC) ASSAY}

Bacterial suspensions were inoculated on microplates containing $180 \mu \mathrm{L}$ of BHI with different concentrations of the active extracts (MIC, 1/2 MIC, 1/4 MIC, 1/8 MIC, and 1/16 MIC) until reaching the final concentration of $10^{6} \mathrm{CFU} \cdot \mathrm{mL}^{-1}$. After, these concentrations were incubated at $37^{\circ} \mathrm{C}$ for $24 \mathrm{~h}$. The supernatant was withdrawn, and the wells were washed three times with $0.85 \%$ saline solution. The remaining bacterial mass was dried at $37^{\circ} \mathrm{C}$ for $15 \mathrm{~min}$ and stained with $200 \mu \mathrm{L}$ of crystal violet $0.1 \%$ for $30 \mathrm{~min}$. Wells were rewashed and dried as previously described, followed by the addition of $300 \mu \mathrm{L}$ of ethanol and the measurement of absorbance at $630 \mathrm{~nm}$. This test was performed twice in triplicate.

\section{CHEMICAL PROFILING}

\section{GC-MS analysis}

GC-MS analysis was carried out on a QP2010 Ultra Shimadzu system, employing the following conditions: column fused silica capillary column Rtx-5MS (30 m; 0.25 mm ID; 0.25 film $\mu \mathrm{m}$ ). Helium (99.999\%) was used as a carrier gas at a constant flow of $1 \mathrm{~mL} / \mathrm{min}$, and an injection volume of 1.0 $\mu \mathrm{L}$ was employed (split ratio of 10:1) at an injector temperature of $290^{\circ} \mathrm{C}$ and an ion source temperature of $200^{\circ} \mathrm{C}$. The oven temperature was programmed at $80^{\circ} \mathrm{C}$ for 5 minutes, then increased to $285^{\circ} \mathrm{C}$ at a $4{ }^{\circ} \mathrm{C}$ rate/min and kept at this temperature for 40 minutes. Mass spectra were taken at $70 \mathrm{eV}$, a scan interval of $0.5 \mathrm{~s}$, and fragments from 35 to $700 \mathrm{Da}$. The MS transfer line temperature was $290^{\circ} \mathrm{C}$.

\section{Identification of phytocomponents}

The compounds were identified using the Wiley 7 library database, together with the National Institute of Standards and Technology (NIST) library. The name, molecular weight, molecular formula, and area under peak of the test materials' components were ascertained.

\section{Production of the herbal soap}

The dichloromethane extract of $P$. ornatus $(250 \mathrm{mg}$ ) was incorporated into a soap, which was formulated according to the BR 1005633-5 patent (Diaz and Pizziolo 2012). Later, the semi-solid mixture was poured into a mold and allowed to solidify. Soap 
without extract was also produced to be used as a reference product.

\section{ANTIBACTERIAL ASSAY OF THE HERBAL SOAP}

\section{In vitro}

The agar-dilution method was employed in an in vitro evaluation. The herbal soap (1.0 g) was dissolved in distilled water $(50 \mathrm{~mL})$ to obtain a $2 \%$ suspension. The suspension was vigorously shaken to dissolve the soap, to disperse the foam, and to homogenize the suspension. Next, $1.0 \mathrm{~mL}$ of the soap solution was added to $20 \mathrm{~mL}$ of sterile molten culture media in Petri-dishes and allowed to set. One-hundred $\mu \mathrm{L}$ of suspension containing $10^{6}$ CFU.mL ${ }^{-1}$ of a resistant 4075 S. aureus strain was then streaked on the plates. After incubation at $37^{\circ} \mathrm{C}$ for $24 \mathrm{~h}$, inhibition zones were compared to the control to observe the presence or absence of microbial growth.

In vivo

Gloves contaminated with $S$. aureus from animals with mastitis infection were used to perform the in vivo evaluation (topical test performed according to our institutional ethics, protocol number 773.182). The herbal soap (1.0 g) was dissolved in distilled water $(100 \mathrm{~mL})$ to obtain a $1 \%$ suspension. This suspension was then vigorously shaken to dissolve the soap, to disperse the foam, and to homogenize it. After, the gloves (12 pairs, 6 for each control soap and herbal soap treatment) were immersed in these solutions for 30 minutes. Before being immersed in the soap, the gloves that the milkers had used to milk the cow's udder, which had been contaminated with $S$. aureus, were swabbed, and the sample was placed in bottles with sterile normal saline solution. After being immersed in both the herbal and control soaps, the gloves were again swabbed, and the samples were placed in separate bottles with normal sterile saline solution. Aliquots from the respective treatments were cultured on an agar plate at $37^{\circ} \mathrm{C}$ for $24 \mathrm{~h}$ to observe the presence or absence of microbial growth.

\section{RESULTS AND DISCUSSION}

According the results observed in the assays, no differences were observed between the two crude extracts of the plant in relation to the antimicrobial activity of the solvent used in this study. The petrol and dichloromethane crude extracts were active, but the dichloromethane was slightly more active than the petrol extract (Table I).

By analyzing the MIC values obtained for the petrol and dichloromethane crude extracts (Table II), it could be concluded that, these values are lower than some values previously found in extract with antimicrobial activity (Duarte et al. 2004, Virtuoso et al. 2005). Based on the MIC values, extracts can have strong ( 0.05 to $\left.0.5 \mathrm{mg} . \mathrm{mL}^{-1}\right)$, moderate $\left(0.6\right.$ to $\left.1.5 \mathrm{mg} \cdot \mathrm{mL}^{-1}\right)$, or weak activity (> $1.5 \mathrm{mg} \cdot \mathrm{mL}^{-1}$ ) (Aligiannis et al. 2001). Using these criteria, the extracts of $P$. ornatus can be considered to be between the strong and moderate inhibitors for the strains used in this study. However, when compared to the positive control, the MIC values were still low.

A biofilm is a group of cells that adhere to any surface and are frequently embedded within a self-produced matrix of an extracellular polymeric substance. This wrapping makes the microorganism highly resistant to antibiotics and difficult to treat. Staphylococcus spp. is known as a commensal agent that can be found on the skin and mucosal surfaces and is the most frequent cause of infections associated with biofilms (Otto 2008). In the present study, the active extracts were evaluated for anti-biofilm activity in subinhibitory concentrations ( 2 x MIC; MIC; $1 \frac{2}{2} \mathrm{MIC}$; $1 / 4 \mathrm{MIC}$; $1 / 8$ MIC and 1/16 MIC) to evaluate Biofilm Inhibitory Concentration (BIC) on pre-formed biofilms. The 
BIC values were between $2 \times$ MIC (Supra MIC), MIC, and $1 / 2$ MIC (Sub MIC) (Table III).

The results showed that active extracts are able to inhibit the formation of biofilms. Concentrations corresponding to the Supra MIC and MIC of dichloromethane extracts were enough to inhibit approximately $100 \%$ of biofilms formed by $S$. aureus ATCC 29313, 3828, 4075, and 4158 . According to table III, the best BIC value (100\% inhibition), obtained for the dichloromethane extract against $S$. aureus, can indicate that this extract inhibit bacterial film formation in the initial phase of adhesion and formation of biofilms. This value was similar to those found for antibiotic substances reported in prior literature (Nostro et al. 2007). The same was observed for Supra MIC and MIC of the crude petrol extract on S. aureus 3828 and ATCC 29313. Concentrations corresponding to Sub MIC of both extracts were enough to inhibit approximately $30-80 \%$ of the biofilms formed by $S$. aureus ATCC 29313, 3828, 4075, 4128, and 4158.

$\mathrm{MIC}$ and BIC results justify the choice of the dichloromethane extract as an antiseptic agent in the form of an herbal soap.

The in vitro results demonstrated that the herbal soap obtained from a dichloromethane crude extract reduces the bacterial load to $89 \pm 3.0 \mathrm{CFU}$ (Figure $1 \mathbf{a}, \mathbf{b}$ ). These results are in agreement with those observed by small farmers.

According to the results observed in the in vivo evaluation (Figure 2 a), microbial growth was observed in the Petri dishes after immersing the milker's gloves in the control soap (Figure 2 b). By contrast, in figure 2 (c) microbial growth was not observed in the Petri dishes after immersing the milker's gloves in the $1 \%$ suspension of herbal soaps with an active extract of $P$. ornathus for $30 \mathrm{~min}$.

The chemical constituents in the petrol and dichloromethane extracts of the aerial parts of $P$. ornatus belong to different chemical groups, according to the GC/MS analysis of the plantextracts. 
TABLE II

MIC values (mg.mL ${ }^{-1}$ ) of extracts from Plectrantus ornatus leaves against Staphylococcus aureus strains.

S. aureus

Crude extracts

$\operatorname{MIC}\left(\mathrm{mg} \cdot \mathrm{mL}^{-1}\right)$

$\begin{array}{lccccc} & \text { ATCC29213 } & 3828 & 4075 & 4125 & 4158 \\ \text { Petrol } & 0.6 & 0.4 & 0.5 & 0.6 & 0.6 \\ \text { loromethane } & 0.6 & 0.5 & 0.7 & 0.6 & 0.5 \\ \text { irox olamine }^{\mathrm{a}} & 0.05 & 0.05 & 0.05 & 0.05 & 0.05\end{array}$

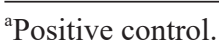

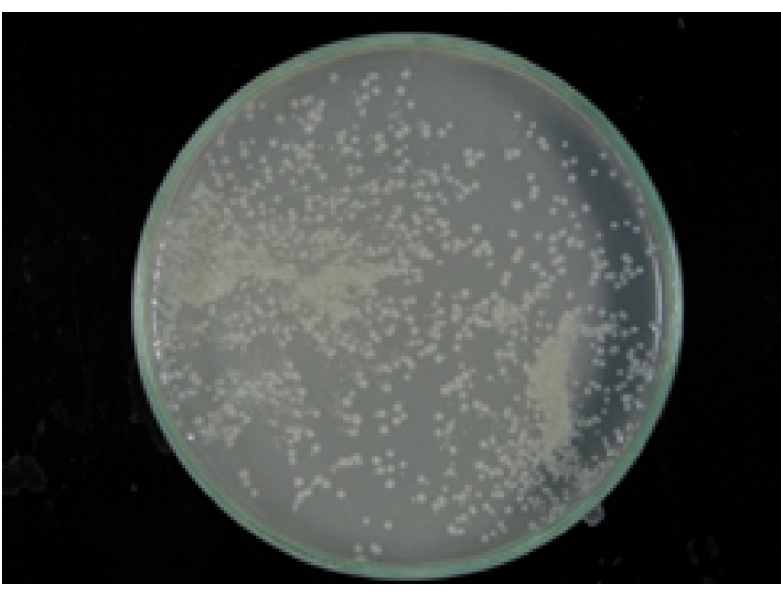

a - Control (soap without dichloromethane extract of $P$. ornathus).

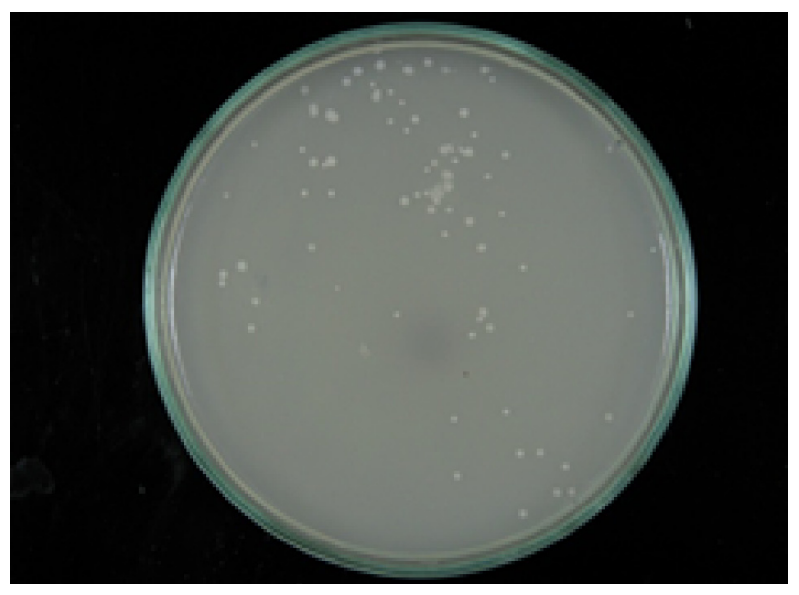

b - Herbal soap with dichloromethane extract of $P$. ornathus (89 $\pm 3.0 \mathrm{CFU})$.

Figure 1 - In vitro antibacterial activities of herbal soap produced with the active extract of $P$. ornathus. Tests were performed in triplicate.

TABLE III

BIC values obtained from the actives extracts of Plectrantus ornatus on Staphylococcus aureus strains.

\begin{tabular}{|c|c|c|c|c|c|c|}
\hline \multirow[t]{2}{*}{ Crude extracts } & \multirow{2}{*}{$\begin{array}{c}\text { MIC } \\
\text { Concentration }\end{array}$} & \multicolumn{5}{|c|}{$\begin{array}{c}\text { S. aureus } \\
\% \text { of inhibition }\end{array}$} \\
\hline & & ATCC29213 & 3828 & 4075 & 4125 & 4158 \\
\hline \multirow{3}{*}{ Petrol } & Supra MIC* & 100 & 100 & 70 & 80 & 50 \\
\hline & $\mathrm{MIC}^{* *}$ & 100 & 100 & 50 & 50 & 50 \\
\hline & Sub MIC*** & 50 & 50 & 50 & 30 & 50 \\
\hline \multirow{3}{*}{ Dichloromethane } & Supra MIC** & 100 & 100 & 100 & 100 & 100 \\
\hline & $\mathrm{MIC}^{* *}$ & 100 & 100 & 100 & 50 & 100 \\
\hline & Sub MIC*** & 50 & 50 & 80 & 50 & 50 \\
\hline Ciclopirox olamine ${ }^{a}$ & & 100 & 100 & 100 & 100 & 100 \\
\hline
\end{tabular}

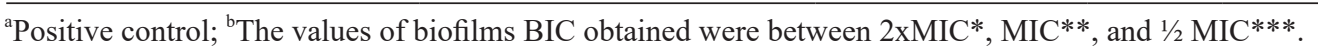




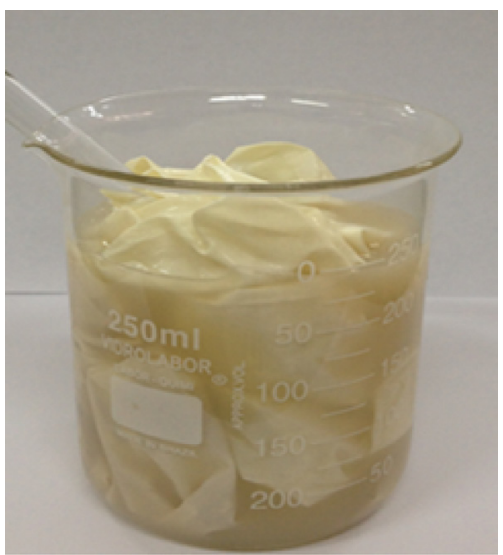

a - Milker's gloves immersing in the soap solution.

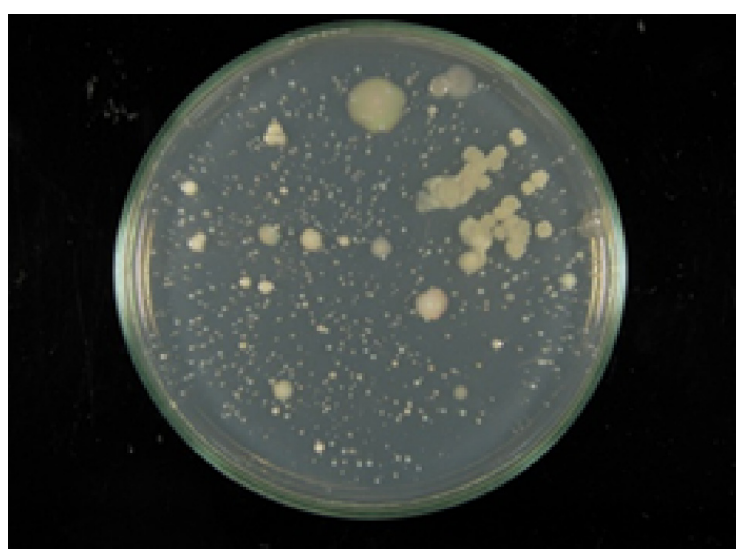

b - Result immersing the milker's gloves in the soup control (without active extract).

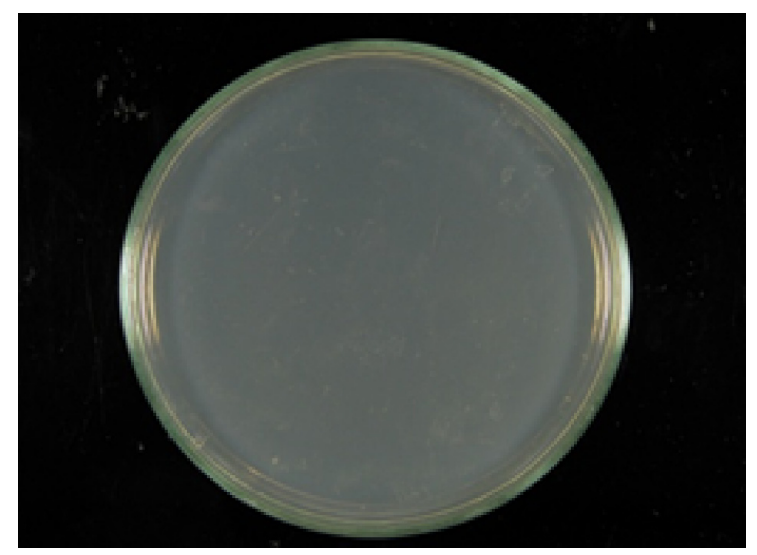

c - Result after the milker's gloves had been immersed in the herbal soap (with active extract).

Figure 2 - In vivo antibacterial activities of the herbal soap with the active extract of $P$. ornatus in the milkers' gloves.

This analysis revealed the presence of compounds like diterpenes, triterpenes, and flavonoids, which are known to exhibit antimicrobial activities that inhibit bacterial growth (Table IV). Therefore, we can assume that the antimicrobial activity observed in crude extracts may well be associated with these types of compounds (Figure 3) (Rijo et al. 2011, Roberto et al. 2007).

\section{CONCLUSIONS}

According to the results obtained in this study, the herbal soap from $P$. ornatus can be used as an antiseptic agent in pre and post-dipping without drawbacks of disinfectants formulated based on iodine or sodium hypochlorite. These can also be used as adjuvant, such as disinfectants for disease control. These herbal soaps demonstrated a high level of inhibition against $S$. aureus from cows' udders and indicates the potential of this plant as an excipient in the production of antiseptic soaps to fight bovine mastitis infections, especially on small farms. Our results validate the use of this plant by small farms to control this disease.

\section{ACKNOWLEDGMENTS}

The authors are grateful to Maria Aparecida V.P. Brito (Embrapa/CNPGL, Juiz de Fora, Minas Gerais), who kindly provided the bacterial strains. We thanks the Conselho Nacional de Desenvolvimento Científico e Tecnológico (CNPq) [grant numbers 470153/2011-3]. 
TABLE IV

Main compounds identified by GC-MS in dichloromethane extract of $P$. ornatus leaves that present previously antibacterial activity.

\begin{tabular}{ccccccc}
\hline No. RT (min) & $\begin{array}{c}\text { Name of the } \\
\text { compound }\end{array}$ & $\begin{array}{c}\text { Molecular } \\
\text { Formula }\end{array}$ & MW & $\begin{array}{c}\text { Peak } \\
\text { area } \\
\mathbf{( \% )}\end{array}$ & References \\
\hline 1 & 16.08 & Forskolin & $\mathrm{C}_{22} \mathrm{H}_{4} \mathrm{O}_{7}$ & 410 & 80 & Rijo et al. 2011 \\
2 & 17.91 & Quercetin & $\mathrm{C}_{15} \mathrm{H}_{10} \mathrm{O}_{7}$ & 302 & 76 & Walker et al. 2009, Manríquez-Torres et al. 2007, Mattana \\
et al. 2010
\end{tabular}

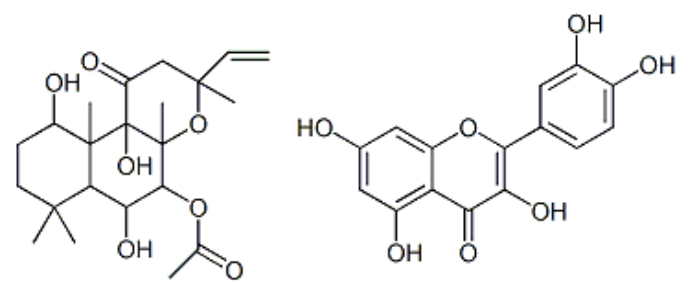

Forskolin

Quercetin<smiles>CCC(CCC(C)C1CCC2C1(C)CCC1C3(C)CCC(O)CC3=CCC12C)C(C)C</smiles><smiles>CCC(/C=C/C(C)C1CCC2C1(C)CCC1C3(C)CCC(O)CC3=CCC12C)C(C)C</smiles>

Stigmasterol<smiles>CC1CCC2(C)CC(C)C3C(=CCC4C3(C)CCC3C(C)(C)C(O)CCC34C)C2C1C</smiles>

$\alpha$-Amirin<smiles>CC1C(=O)CCC2C1(C)CCC1C2(C)CCC2(C)C3CC(C)(C)CCC3(C)CCC12C</smiles>

Friedelin

Figure 3 - Compounds identified by GC-MS in dichloromethane extract of $P$. ornatus leaves. 


\section{REFERENCES}

ALIGIANNIS N, KALPOUTZAKIS E, MITAKU S AND CHINOU IB. 2001. Composition and antimicrobial activity of the essential oils of two Origanum species. J Agric Food Chem 49: 4168-4170.

ANNAN K, ADU F AND GBEDEMA SY. 2009. Friedelin: A bacterial resistance modulator from Paulinia Pinnata L. J Sci Tech (Ghana) 29: 152-159.

BRASILEIRO BG, PIZZIOLO VR, RASLAN DS, JAMAL CM AND SILVEIRA D. 2006. Antimicrobial and cytotoxic activities screening of some brazilian medicinal plants used in Governador Valadares district. Braz J Pharm Sci 42: 195-202.

CLSI - CLINICAL AND LABORATORY STANDARDS INSTITUTE. 2009. Methods for dilution antimicrobial susceptibility tests for bacteria that grow aerobically; approved standard eighth edition. Document M07-A8. Wayne, PA: CLSI.

DIAZMANAND PIZZIOLO VR. 2012. Processo de fabricação e formulação de sabonete para fins cosmecêuticos contendo óleo de semente de Macaúba (Acronomia aculeata) e o produto obtido. Brazil Patent BR 1005633-5.

DIAZ MAN, ROSSI CC, MENDONÇA VR, SILVA DM, RIBON ABO, AGUILAR AP AND MUÑOZ GD. 2010. Screening of medicinal plants for antibacterial activities on Staphylococcus aureus strains isolated from bovine mastitis. Braz J Pharmacog 20: 724-728.

DUARTE MCT, FIGUEIRA GM, PEREIRAB, MAGALHÃES PM AND DELARMELINA C. 2004. Atividade antimicrobiana de extratos hidroalcólicos de espécies da coleção de plantas medicinais CPQBA/UNICAMP. Braz J Pharmacog 14: 6-8.

EDILU A, ADANE L AND WOYESSA D. 2015. In vitro antibacterial activities of compounds isolated from roots of Caylusea abyssinica. Ann Clin Microbiol Antimicrob 14: 15. (DOI 10.1186/s12941-015-0072-6).

GOWDU VISWANATHAN MB, ANANTHI JDJ AND KUMAR PS. 2012. Antimicrobial activity of bioactive compounds and leaf extracts in Jatropha tanjorensis. Fitoterapia 83: 1153-1159.

JUE SG, DAWSON GW AND BROGDEN RN. 1985. Ciclopirox olamine 1\% cream. Drugs 29: 330-341.

LUKHOBA CW, SIMMONDS MS AND PATON AJ. 2006. Plectranthus: a review of ethnobotanical uses. J Ethnopharmacol 103: 1-24.

MANRÍQUEZ-TORRES JJ, ZÚÑIGA-ESTRADA A, GONZÁLEZ-LEDESMA M AND TORRES-VALENCIA JM. 2007. The antibacterial metabolites and proacacipetalin from Acacia cochliacantha. J Mex Chem Soc 51: 228-231.

MARINHO ML, ALVES MS, RODRIGUES MLC, ROTONDANO TEF, VIDAL IF, SILVA WW AND ATHAYDE ACR. 2007. A utilização de plantas medicinais em medicina veterinária: um resgate do saber popular. Rev Bras P1 Med 9: 64-69.

MATTANA CM, SATORRES SE, SOSA A, FUSCO M AND ALCARÁZ LE. 2010. Antibacterial activity of extracts of Acacia aroma against methicillin-resistant and methicillinsensitive Staphylococcus. Braz J Microbiol 41: 581-587.

MOKOKA TA, MCGAW LJ, MDEE LK, BAGLA VP, IWALEWA EO AND ELOFF JN. 2013. Antimicrobial activity and cytotoxicity of triterpenes isolated from leaves of Maytenus undata (Celastraceae). BMC Complement Altern Med 13: 1.

NASCIMENTO GGF, LOCATELLI J, FREITAS PC AND SILVA GL. 2000 Antibacterial activity of plant extracts and phytochemicals on antibiotic-resistant bacteria. Braz J Microbiol 31: 247-256.

NOSTRO A, ROCCARO AS, BISIGNANO G, MARINO A, CANNATELLI MA, PIZZIMENTI FC AND BLANCO AR. 2007. Effects of oregano, carvacrol and thymol on Staphylococcus aureus and Staphylococcus epidermidis biofilms. J Med Microbiol 56: 519-523.

OTTO M. 2008. Staphylococcal biofilms. In Bacterial biofilms (p. 207-228). Springer Berlin Heidelberg.

RIJO P, DUARTE A, FRANCISCO AP, SEMEDOLEMSADDEK T AND SIMÕES MF. 2014. In vitro Antimicrobial Activity of Royleanone Derivatives Against Gram-Positive Bacterial Pathogens. Phytother Res 28: 76-81.

RIJO P, RODRÍGUEZ B, DUARTE AAND FATIMA SIMOES M. 2011. Antimicrobial properties of Plectranthus ornatus extracts, 11-acetoxyhalima-5, 13-dien-15-oic acid metabolite and its derivatives. Nat Prod J 1: 57-64.

ROBERTO L, KENTOPFF MR, MACHADO MIL, SILVA MGV, MORAIS SM AND BRAZ-FILHO R. 2007. Diterpenos tipo abietano isolados de Plectranthus barbatus Andrews. Quim Nova 30: 1882-1886.

STAVRI M, PATON A, SKELTON BW AND GIBBONS S. 2009. Antibacterial diterpenes from Plectranthus ernstii. J Nat Prod 72: 1191-1194.

VIRTUOSO S, DAVET A, DIAS JFG, CUNICO MM, MIGUEL MD, OLIVEIRA AB AND MIGUEL OG. 2005. Estudo preliminar da atividade antibacteriana das cascas de Erythrina velutina Willd., Fabaceae (Leguminosae) Braz J Pharmacog 15: 137-142.

WALKER CI, ZANOTTO CZ, CERON CS, POZZATTI P, ALVES SH AND MANFRON SH. 2009. Atividade farmacológica e teor de quercetina de Mirabilis jalapa L. Lat Am J Pharm 28: 241-246.

WELLSOW J, GRAYER RJ, VEITCH NC, KOKUBUN T, LELLI R, KITE GC AND SIMMONDS MS. 2006. Insectantifeedant and antibacterial activity of diterpenoids from species of Plectranthus. Phytochemistry 67: 1818-1825.

YINUSA I, GEORGE NI, SHUAIBU UO AND AYO RG. 2014. Bioactivity of stigmasterol isolated from the aerial part of Spillanthes acmella (Murr) on selected microorganism. Int. J Curr Microbiol App Sci 3: 475-479. 